\title{
PENGEMBANGAN SOFTWARE MULTIMEDIA INTERAKTIF PEMBELAJARAN IPA UNTUK MENINGKATKAN HASIL BELAJAR DI SEKOLAH MENENGAH PERTAMA
}

\author{
Arif Harbani \\ Dosen Tetap Program Studi Teknik Informatika \\ Sekolah Tinggi Ilmu Komputer BINANIAGA \\ Email: arifharbani@gmail.com
}

\begin{abstract}
This study aims to produce interactive multimedia software in science learning on theme of healthy living with clean water and analyze the effectiveness of interactive multimedia software in increasing interest in learning and mastery of concepts. Subjects were students of class $7^{\text {th }}$ in Junior High School 2 Ciseeng. The method used in this research is the Research and Development and followed up with a pre-experimental research. The approach used in this study were adopted from Sukmadinata et al and modified from Borg and Gall models through three stages, namely a preliminary study, product development, and product test. The evaluation of interactive multimedia sofware products done by material and media experts. Data learning resultobtained based on measurements with a written test. Results of evaluation by experts showed the average score for the material, technique, display design, and the program aspects is 3.8 (very good category. Classical learning completeness values by $93 \%$ according to criteria to be achieved is $\geq 85 \%$.Based on the result, it can be concluded that the interactive multimedia software in science learning very good and effective to increase learning result.
\end{abstract}

Keywords:Interactive multimedia software;Science learning; Learning result.

\begin{abstract}
ABSTRAK
Penelitian ini bertujuan menghasilkan software multimedia interaktif pembelajaran IPA dan menganalisis keefektifan software multimedia interaktif yang dikembangkan dalam meningkatkan hasil belajar. Subyek penelitian adalah siswa kelas VII SMP Negeri 2 Ciseeng Kabupaten Bogor tahun pelajaran 2016/2017. Metode yang digunakan dalam penelitian ini adalah Research and Development dan ditindaklanjuti dengan penelitian pre-experimental. Pendekatan yang digunakan dalam penelitian ini diadopsi dari Sukmadinata, dkk. dan dimodifikasi dari model Borg dan Gall melalui tiga tahapan, yaitu studi pendahuluan, pengembangan produk, dan uji produk. Evaluasi produk software multimedia interaktif dilakukan oleh ahli materi dan ahli media. Data hasil belajar diperoleh berdasarkan pengukuran dengan tes tertulis. Hasil evaluasi oleh para ahli menunjukkan rerata skor untuk aspek materi, teknik, desain tampilan, dan program adalah 3,8 (kategori sangat baik). Nilai ketuntasan belajar klasikal sebesar 93\% sesuai dengan kriteria yang ingin dicapai yaitu $\geq 85 \%$. Berdasarkan hasil penelitian, dapat disimpulkan bahwa software multimedia interaktif pembelajaran IPA sangat baik dan efektif dalam meningkatkan hasil belajar.
\end{abstract}

Kata Kunci: Software multimedia interaktif, Pembelajaran IPA, Hasil belajar.

\section{PENDAHULUAN}

Seorang pendidik harus mampu menghadirkan inovasi dalam menghadirkan media pembelajaran yang dapat mendorong perhatian siswa agar belajar lebih optimal sehingga dapat meningkatkan hasil belajar. Sebagaimana pernyataan Keller (2015): "Instructional designers can also grab learners' attention by employing a variety of different 
media".Pengembangan media dimaksudkan untuk mempermudah guru dalam menyampaikan materi pembelajaran. Salah satu fungsi utama media pembelajaran adalah sebagai alat bantu mengajar yang turut mempengaruhi iklim, kondisi, dan lingkungan belajar yang ditata dan diciptakan oleh guru (Arsyad, 2013).

Software multimedia interaktif sebagai media pembelajaran berbasis komputer (Computer Based Learning) memberi kesempatan kepada siswa untuk berinteraksi, sehingga menghasilkan pembelajaran yang aktif, kreatif, menyenangkan dan bermakna (PAKEMB). Teknologi multimedia telah menjadikan pembelajaran berbasis komputer menjadi lebih menarik dan informasi yang ditampilkan lebih lengkap karena disajikan dalam wujud kombinasi teks, gambar, video, audio, dan bahkan disertai animasi (Candiasa, 2012). Multimedia mampu menarik perhatian siswa untuk belajar dengan motivasi tinggi karena pada multimedia, teks dapat "dihidupkan" dengan menambahkan tampilan gambar, suara, musik, video, dan animasi. Sebagaimana ungkapan Vaishnav and Parage (2013): "The students are able to graps more and understand the subject in better way if it is presented to them in audio-visual form". Pekerjaan mengembangkan multimedia interaktif semakin mudah dengan dikembangkannya software seperti Adobe Flash yang dapat menggabungkan teks, gambar, grafik, suara, video, dan animasi menjadi suatu program multimedia.

Berdasarkan pengamatan yang dilakukan penulis di SMPN 2 Ciseeng, terdapat berbagai masalah dalam pembelajaran IPA, antara lain: 1) Rendahnya hasil belajar siswa terhadap pembelajaran IPA. Berdasarkan analisis hasil ulangan harian siswa sebelumnya, nilai siswa secara klasikal hanya $60 \%$ saja yang dapat mencapai Kriteria Ketuntasan Minimal (KKM) yang ditetapkan di SMPN 2 Ciseeng, yaitu 70; 2)Guru masih dominan dengan metode ceramah dan penggunaan media pembelajaran berupa buku teks, Lembar Kegiatan Siswa (LKS), dan papan tulis dalam menyampaikan materi pembelajaran; 3) Sarana komputer yang dimiliki sekolah belum digunakan secara optimal.

Berdasarkan paparan di atas, maka kebutuhan pengembangan media pembelajaran berbentuksoftwaresangat diperlukanuntuk memotivasi siswa dalam mengikuti proses pembelajaran.Penulistelah mengembangkan media pembelajaran softwaremultimedia interaktif pembelajaran IPA yang diharapkan dapat membantu siswa dalam meningkatkan hasil belajar.

Rumusan masalah dalam penelitian ini adalah:

1. Bagaimakah profil softwaremultimedia interaktif pembelajaran IPA yang dapat meningkatkan hasil belajar siswa?

2. Bagaimanakah keefektifan softwaremultimedia interaktif pembelajaran IPA yang dikembangkan dalam meningkatkan hasil belajar siswa?

Adapun tujuan penelitian ini dimaksudkan untuk: 
1. Menghasilkan softwaremultimedia interaktif pembelajaran IPA.

2. Menganalisis keefektifan softwaremultimedia interaktif pembelajaran IPA yang dikembangkan dalam meningkatkan hasil belajar siswa.

\section{METODE}

\section{A. Tempat dan Waktu Penelitian}

Penelitian telah dilaksanakan pada kelas 7 di SMP Negeri 2 Ciseeng Kabupaten Bogor. Kegiatan penelitian dilakukan dari bulan Junisampai dengan bulanSeptember 2017.

\section{B. Metode Penelitian}

Penelitian ini menggunakan metode penelitian dan pengembangan atau Research and Development. Produk yang dikembangkan adalah softwaremultimedia interaktif pembelajaran IPA untuk meningkatkan hasil belajar siswa SMP. Penelitian dan pengembangan merupakan metode penelitian yang digunakan untuk menghasilkan produk tertentu, dan menguji keefektifan produk tersebut supaya dapat berfungsi di masyarakat luas (Sugiyono, 2014).

Efektifitas softwaremultimedia interaktif dalam penelitian ini menggunakan preexperimentaldesign. Bentuk desain dalam penelitian ini adalah one-shot case study design (one-group posttest-only study). Fraenkel et al menyatakanbahwa "in the oneshot case study design, a single group is exposed to a treatment or event and a dependent variable is subsequently observed (measured) to assess the effect of the treatment" (Fraenkel, 2015).

\section{Langkah - langkah Penelitian dan Pengembangan}

Model yang digunakan dalam penelitian ini diadopsi dari model penelitian Sukmadinata (2011) yang terdiri atas tiga tahap: 1) Studi Pendahuluan; 2) Pengembangan Produk; 3) Uji Produk.

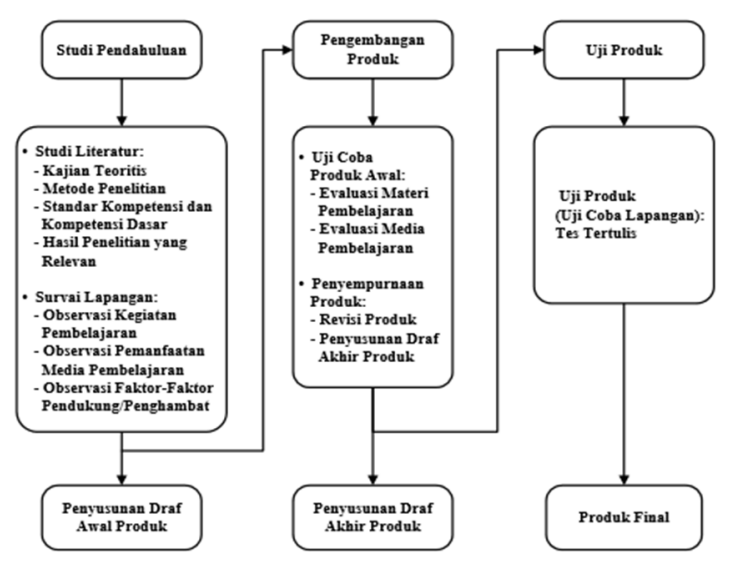

Gambar 1. Langkah-Langkah Penelitian dan Pengembangan 


\section{Desain Produk}

Setelah studi pendahuluan dilakukan, disusun sebuah desain produk yang diwujudkan dalam bagan alur program software. Langkah-langkah penyusunan desain produk adalah:

1. Menentukan Isi Materi

Langkah pertama adalah mengkaji kurikulum, Standar Kompetensi dan Kompetensi Standar dari disiplin ilmu biologi, kimia, dan fisika. Menentukan tema tipeconnected yaitu "Air Bersih". Materi pembelajaran IPA yang akan dipadukan yaitu: a) Pengelolaan Lingkungan; b) Asam,Basa, dan Garam; dan c) Pemisahan Campuran.

2. Pembuatan Flow Chart

Mendesain alur berpikir isi program yang disebut flow chart sebagaimana gambar 2 berikut ini.

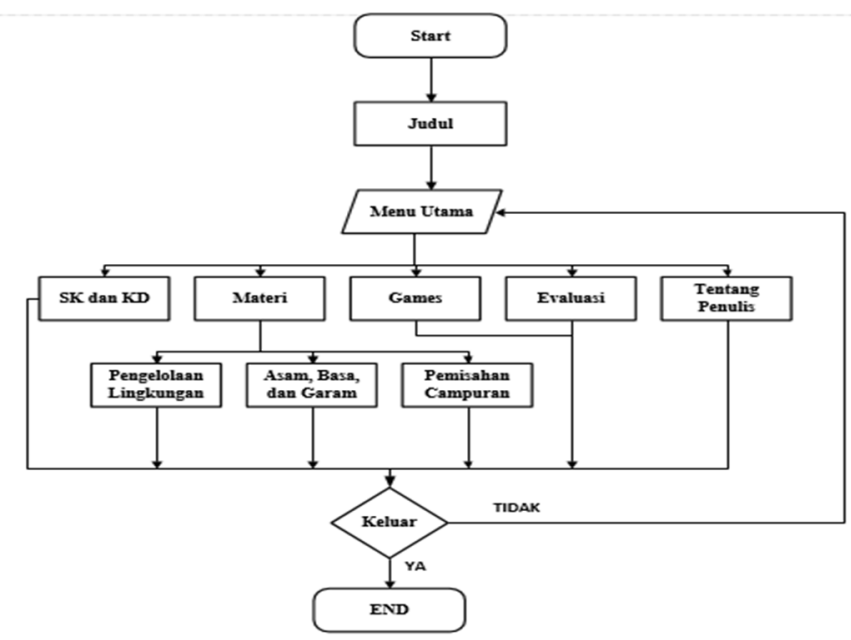

Gambar 2. Flow Chart Software

3. Penelitian Naskah (Story board)

Story board merupakan penjabaran dari flow chart. Berikut ini menu-menu yang terdapat dalam software, yaitu:

a. SK dan KD, menyajikan standar kompetensi, kompetensi dasar, dan tujuan pembelajaran.

b. Materi terdiri dari: 1) Pengelolaan Lingkungan;2) Asam,Basa, dan Garam; 3) Pemisahan Campurandisajikan dalam bentuk gambar, animasi, video tentang fakta dan fenomena.

c. Games, menyajikan permainan yang berhubungan dengan tema.

d. Evaluasi, berisi soal-soal yang mencakup 3 bahasan.

e. Tentang Penulis, berisi data diri singkat Peneliti.

4. Penyusunan Draf Awal Produk 
Langkah terakhir adalah produksi, proses pengambilan gambar, animasi, video, dan menyusun teks yang disusun menggunakan program Adobe Flash CS4.

\section{E. Instrumen Penelitian}

Variabel penelitian dan pengembangan ini yaitu softwaremultimedia interaktif pembelajaran IPA (variabel $\mathrm{X}$ ) dan hasil belajar (Y2). Dilakukan penyusunan evaluasisoftware dan soal tes hasil belajar untuk mengetahui profil dan keefektifan softwaremultimedia interaktif.

1. Evaluasi Software Multimedia Interaktif Pembelajaran IPA

Menilai profil softwaremultimediainteraktif pembelajaran IPA. Kisi-kisi evaluasi materi pembelajaran IPAyang dinilai olehahli materi disajikan pada tabel 2 berikut ini.

Tabel 2. Kisi-Kisi Evaluasi MateriPembelajaran IPA

\begin{tabular}{|c|l|l|}
\hline No. & \multicolumn{1}{|c|}{ Aspek } & \multicolumn{1}{c|}{ No. Soal } \\
\hline 1 & Materi & $1,2,3,4,5,6,7,8$ \\
\hline 2 & Teknis & $8,9,10$ \\
\hline
\end{tabular}

Kisi-kisi evaluasisoftwaremultimedia interaktif pembelajaran IPAyangdinilai oleh ahli media terdapat pada tabel 3 .

Tabel 3. Kisi-Kisi EvaluasiMedia Pembelajaran IPA

\begin{tabular}{|c|l|c|}
\hline No. & \multicolumn{1}{|c|}{ Aspek } & \multicolumn{1}{c|}{ No. Soal } \\
\hline 1 & Desain Tampilan & $1,2,3,4,5,6,7,8,9,10$ \\
\hline 2 & Program & $11,12,13,14,15,16,17,18,19,20$ \\
\hline
\end{tabular}

2. Tes Hasil Belajar

Hasil belajar diukur dengan menggunakan tes pilihan gandasebanyak 30 soal dengan empat pilihan jawaban. Kisi-kisi soal disajikan pada tabel 4.

Tabel 4. Kisi-Kisi Soal

\begin{tabular}{|c|l|c|c|c|c|}
\hline \multirow{2}{*}{ No } & \multicolumn{1}{|c|}{ Indikator } & \multicolumn{3}{c|}{ Jenjang Kognitif (Nomor Soal) } \\
\cline { 3 - 5 } & & $\mathrm{C} 1$ & $\mathrm{C} 2$ & $\mathrm{C} 3$ & $\mathrm{C} 4$ \\
\hline 1. & Menjelaskan pencemaran air & & 1,2 & & \\
\hline 2. & Membedakan ciri-ciri air bersih dan air tercemar & & $3,4,5$ & & \\
\hline 3. & Mengklasifikasikan zat penyebab pencemaran air & & 6,7 & & \\
\hline 4. & $\begin{array}{l}\text { Mengidentifikasi aktivitas manusia yang } \\
\text { menyebabkan pencemaran air }\end{array}$ & $8,9,10$ & & & 11,12, \\
\hline 5. & Menganalisis dampak pencemaran air & & & & 13,14 \\
\hline 6. & Menunjukkan cara menanggulangi pencemaran air & & & \\
\hline 7. & $\begin{array}{l}\text { Menyebutkan indikator yang digunakan untuk } \\
\text { menentukan sifat asam dan sifat basa pada air }\end{array}$ & 17,18 & & \\
\hline 8. & $\begin{array}{l}\text { Menggunakan indikator yang tepat untuk mengukur } \\
\text { pH air }\end{array}$ & & & & \\
\hline 9. & $\begin{array}{l}\text { Mengidentifikasi sifat asam dan basa pada air dengan } \\
\text { mengguna-kan indikator asam basa }\end{array}$ & 20,21 & & & 22,23 \\
\hline 10. & $\begin{array}{l}\text { Menganalisis pH air bersih dan air tercemar dengan } \\
\text { menggunakan indikator asam basa }\end{array}$ & & & & \\
\hline
\end{tabular}


p-ISSN : 2087-3891 dan e-ISSN : 2597-8918

\begin{tabular}{|c|l|c|c|c|c|}
\hline 11. & Mendefinisikan pengertian filtrasi & 24,25 & & & \\
\hline 12. & $\begin{array}{l}\text { Memahami pengolahan air secara fisika, biologi, dan } \\
\text { kimia }\end{array}$ & $\begin{array}{c}26,27, \\
28\end{array}$ & & \\
\hline 13. & Membuat alat penjernih air sederhana & & 29,30 & \\
\hline
\end{tabular}

Keterangan: $\mathrm{C} 1$ : Mengingat C3: Mengaplikasikan

C2: Memahami C4: Menganalisis

\section{F. Teknik Analisa Data}

1. Data Hasil EvaluasiSoftware Multimedia Interaktif

Teknik analisis data hasil evaluasi oleh para ahli terhadap softwaremultimedia interaktif menggunakan skala Likert. Instrumen angket evaluasi oleh ahli materi berjumlah 10 pernyataan dan instrumen angket evaluasi oleh ahli media berjumlah 20 terdiri atas 4 kategori pilihan dengan kriteria sebagai berikut: Sangat Tidak Baik $(\mathrm{STB})=1$, Tidak Baik $(\mathrm{TB})=2$, Baik $(B)=3$, dan Sangat Baik $(\mathrm{SB})=4$. Skor evaluasi dihitung dengan menggunakan rumus:

$$
=\frac{\text { Jumlah Skor yang diharapkan }}{\text { Jumlah butir pertanyaan }}
$$

Perolehan hasil perhitungan diinterpretasikan berdasarkan tabel kriteria evaluasi berikut ini.

Tabel 5. Kriteria Evaluasi MultimediaInteraktif

\begin{tabular}{|c|c|}
\hline Rerata Skor & Kategori \\
\hline $3,26-4,00$ & Sangat Baik \\
\hline $2,51-3,25$ & Baik \\
\hline $1,76-2,50$ & Kurang Baik \\
\hline $1,01-1,75$ & Tidak Baik \\
\hline
\end{tabular}

2. Data Hasil Tes Tertulis

Data untuk hasil tes tertulis dianalisis dengan menghitung nilai hasil postes (nilai ulangan II) setiap siswa. Rumus untuk menghitung ketuntasan belajar individu adalah sebagai berikut:

$$
\text { Nilai }=\frac{\text { Jumlah jawaban benar }}{\text { Jumlah Soal }} \times 100
$$

Skor ketuntasan belajar individu digunakan untuk mengetahui persentase ketuntasan belajar secara klasikal dengan rumus:

$$
\text { Persentase Ketuntasan Belajar }(100 \%)=\frac{\text { Jumlah Siswa Tuntas Belajar }}{\text { Jumlah Seluruh Siswa }} \times 100 \%
$$

Ketuntasan belajar klasikal dinyatakan berhasil jika persentase ketuntasan belajar siswa yang memperoleh nilai sesuai Kriteria Ketuntasan Minimal (KKM) sekurang-kurangnya $85 \%$ dari jumlah seluruh siswa di kelas. KKM untuk mata pelajaran IPA di SMP Negeri 2 Ciseeng adalah 70, dengan demikian softwaredinyatakan efektif dalam meningkatkan hasil belajar IPA apabila $\geq 85 \%$ siswa memperoleh nilai $\geq$ KKM. 


\section{HASIL DAN PEMBAHASAN}

\section{A. HASIL DESAIN PRODUK}

Hasil setiap tahap pengembangan SoftwareMultimedia Interaktif Pembelajaran IPA dijelaskan sebagai berikut:

1. Hasil Studi Pendahuluan

a. Hasil Studi Literatur

Dilakukan analisis kebutuhan yang diawali dengan mengumpulkan data tentang teori-teori yang berkaitan dengan softwaremultimedia interaktif dan pembelajaran IPA, metode penelitian, model penelitian dan pengembangan, Standar Kompetensi (SK) dan Kompetensi Dasar (KD) mata pelajaran IPA di SMP untuk menentukan tema yang menjadi dasar dalam pengembangan produk.

b. Hasil Survai Lapangan

Survai lapangan dilakukan untuk mengidentifikasi pelaksanaan KBMpembelajaran IPA, optimalisasi pemanfaatan media pembelajaran, dan faktor-faktor penghambat dan pendukung. Hasil identifikasi permasalahan di sekolah adalah siswa kurang tertarik dalam pembelajaran IPA karena kegiatan pembelajaran masih bersifat konvensional. Penggunaan media pembelajaran belum dilakukan secara optimal karena guru masih dominan menggunakan media berupa buku teks, Lembar Kegiatan Siswa (LKS), dan papan tulis. Faktor pendukung di sekolah antara lain terdapat ruang laboratorium IPA dan komputer yang dapat dimanfaatkan sebagai sarana belajar mengajar. Permasalahan dapat diatasi dengan membuat media pembelajaran IPA berupa softwaremultimedia interaktif dengan memanfaatkan potensi yang ada yaitu sumber daya manusia dan sarana komputer yang dimiliki sekolah.

2. Hasil Pengembangan Produk

a. Pengembangan Desain Produk

Pengembangan produk software diawali dengan menentukan isi materi, pembuatan flow chart(Gambar 1) dan story board berdasarkan pada studi literatur. Selanjutnya dilakukan penyusunan draf awal produk. Produk softwaremultimedia interaktif pembelajaran IPA dikembangkan dengan menggunakan softwareadobeflashCS4. Tema air bersih merupakan materi IPA yang terdiri dari kajian fisika, kimia, dan biologi. Setiap kajian terdiri atas satu bahasan pokok yang saling berkaitan. Produk yang dihasilkan berisi teks dan audio yang dilengkapi dengan gambar, animasi, dan video untuk memudahkan siswa memahami materi pembelajaran. Berikut ini tampilan profil softwaremultimedia interaktif pembelajaran IPA: 
1) Judul

Halaman opening menunjukkan judul dari multimedia interaktif yaitu "Air Bersih”. Tampilan judul disajikan pada gambar 3.

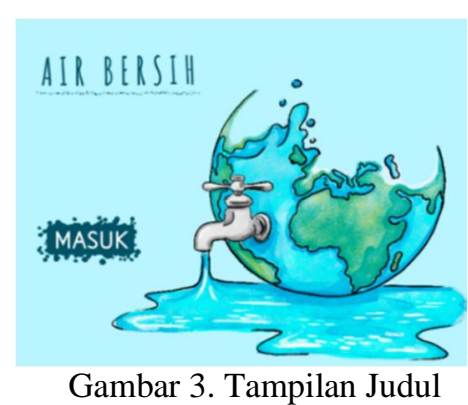

2) Beranda

Beranda memfasilitasi petunjuk isi media yang memuat menu: a) SK dan KD, b) Materi, c) Games, d) Evaluasi, e) Tentang Penulis. Tampilan beranda disajikan pada gambar 4 .

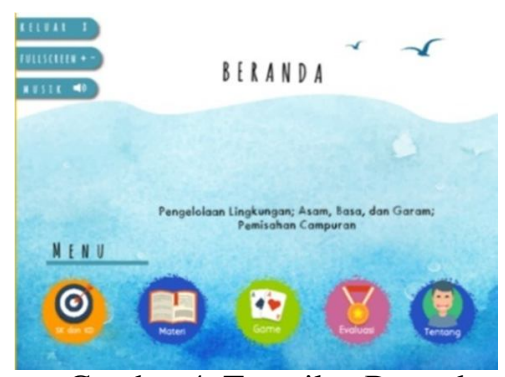

Gambar 4. Tampilan Beranda

3) SK dan KD

SK dan KD pada media ini memuat Standar Kompetensi, Kompetensi Dasar dan indikator pencapaian kompetensi serta tujuan pembelajaran. Berikut ini tampilan SK dan KD yang disajikan pada gambar 5.

4) Materi

Materi tema air bersih memuat pokokbahasan: pengelolaan lingkungan; asam, basa, dan garam; dan pemisahan campuran. Materi dilengkapi dengan teks, gambar, audio, animasi, dan video untuk menarik perhatian dan memudahkan siswa memahami materi. Tampilan menu materi disajikan pada gambar 6.

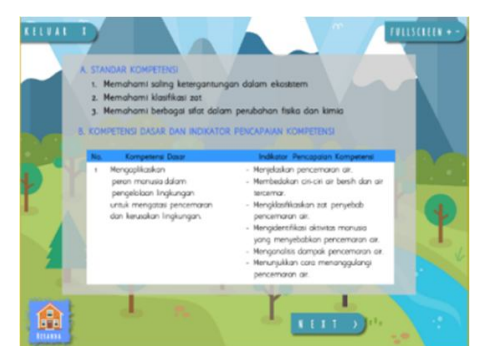

Gambar 5. Tampilan SK dan KD

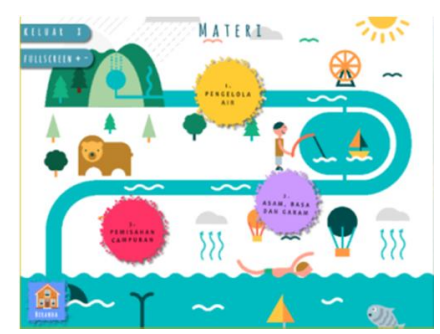

Gambar 6. Tampilan Menu Materi 


\section{5) Games}

Pada menu games disajikan game "penjelajahan si water" dan "mengukur $\mathrm{pH}$ " sesuai dengan tema dalam pembelajaran IPA. Kehadiran gamesdalam software diharapkan lebih menarik minat belajar siswa sehingga pembelajaran menjadi menyenangkan. Tampilan menu games disajikan pada gambar 7.

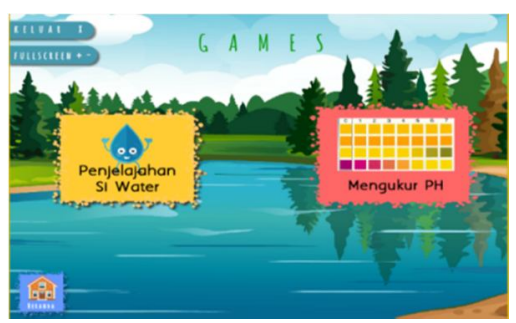

Gambar 7. Tampilan Menu Games

6) Evaluasi

Pada softwarediberikan soal-soal evaluasi untuk mengukur sejauh mana siswa menguasai materi pembelajaran IPA tema air bersih yang terdiri atas tiga bahasan pokok.Tampilan menu evaluasi disajikan pada gambar 8 .

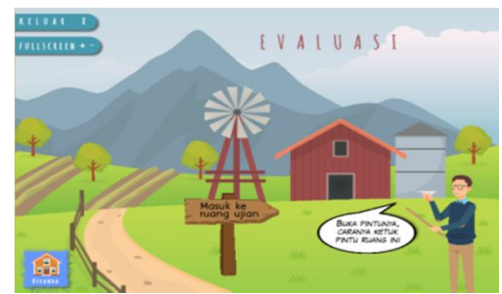

Gambar 8. Tampilan Menu Evaluasi

7) Tentang Penulis

Berisi profil penulis.Penampilan profil penulisdisajikan pada gambar 9.

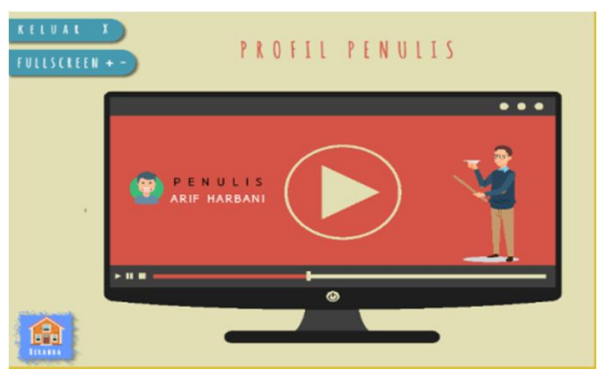

Gambar 9. Tampilan Tentang Penulis

b. Hasil Uji Coba Produk Awal

Pada tahap ini dilakukan "uji coba di atas meja" yang dilakukan oleh ahli materi dan ahli media untuk menilai profil softwaremultimediainteraktif pembelajaran IPA. Hasil evaluasi softwareoleh ahli materi disajikan pada tabel 6.

Tabel 6. Hasil Evaluasi Softwareoleh Ahli Materi

\begin{tabular}{|c|c|c|c|}
\hline No. & Aspek & Rerata Skor & Kategori \\
\hline 1 & Materi & 3,6 & Sangat Baik \\
\hline
\end{tabular}


p-ISSN : 2087-3891 dan e-ISSN : 2597-8918

\begin{tabular}{|l|c|c|c|}
\hline 2 & Teknis & 3,7 & Sangat Baik \\
\hline \multicolumn{2}{|c|}{ Rerata Skor } & 3,6 & Sangat Baik \\
\hline
\end{tabular}

Hasil evaluasi oleh ahli media disajikan pada tabel 7.

Tabel 7. Hasil Evaluasi SoftwareMultimedia Interaktif oleh Ahli Media

\begin{tabular}{|c|c|c|c|}
\hline No. & Aspek & Rerata Skor & Kategori \\
\hline 1 & Desain Tampilan & 3,8 & Sangat Baik \\
\hline 2 & Program & 3,9 & Sangat Baik \\
\hline \multicolumn{2}{|r|}{ Rerata Skor } & 3,6 & Sangat Baik \\
\hline
\end{tabular}

Revisi produk dilakukan berdasarkan saran dan hasil evaluasi dari para ahli.

Jika nilai yang diperoleh $<2,51$, maka media perlu direvisi

3. Hasil Uji Produk

Rekapitulasi nilai tes tertulis sebelumnya (nilai ulangan I) dan nilai tes tertulis (nilai ulangan II) dapat dilihat pada tabel 8 di bawah ini.

Tabel 8. Rekapitulasi Nilai Tes Tertulis

\begin{tabular}{|c|l|c|c|}
\hline \multirow{2}{*}{ No } & \multicolumn{1}{|c|}{ Pencapaian } & \multicolumn{2}{|c|}{ Nilai Ulangan } \\
\cline { 3 - 4 } & & I & II \\
\hline 1. & Nilai Tertinggi & 85 & 100 \\
\hline 2. & Nilai Terendah & 43 & 67 \\
\hline 3. & Rerata Nilai & 70 & 87 \\
\hline 4. & Ketuntasan Belajar Klasikal (\%) & 60 & 93 \\
\hline 5. & Ketidaktuntasan Belajar Klasikal (\%) & 40 & 6,7 \\
\hline
\end{tabular}

Diagram batang peningkatan nilai tes tertulis disajikan pada gambar 11, diagram batang peningkatan rerata nilai tes tertulis disajikan pada gambar 12, diagram batang peningkatan persentase ketuntasan belajar klasikal dapat dilihat pada gambar 13 .

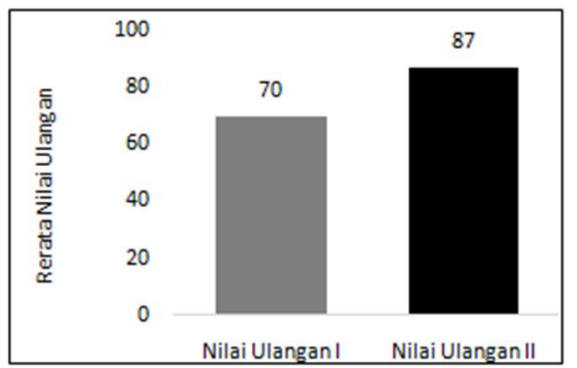

Gambar 11. Diagram Peningkatan Nilai Tes Tertulis

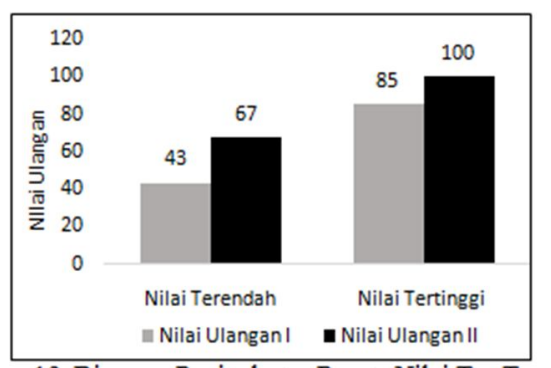

Gambar 12. Diagram Peningkatan Rerata Nilai Tes Tertulis

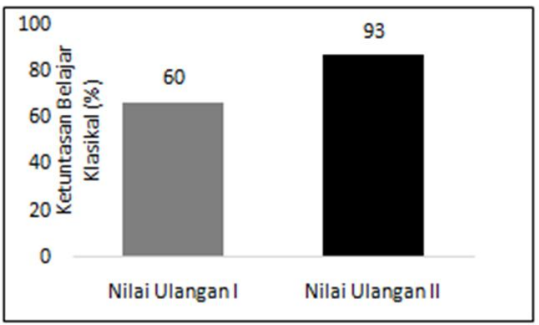

Gambar 13. Diagram PeningkatanPersentase KetuntasanBelajar Klasikal

\section{B. PEMBAHASAN}

1. SoftwareMultimedia Interaktif Pembelajaran IPA 
Berdasarkan hasil evaluasi oleh ahli materi (Tabel 6) diketahui bahwa softwaremultimedia interaktif pembelajaran IPA menunjukkan rerata skor yang diperoleh untuk aspek materi dan aspek teknis termasuk kategori sangat baik. Setelah menganalisis hasil evaluasi oleh ahli materi mengenai pembelajaran IPA (kategori sangat baik)dan tidak ada saran perbaikan dari ahli materi, maka materi padasoftware tidak dilakukan revisi dan dapat dipergunakan dalam uji produk akhir. Komentar yang diberikan oleh ahli materi bahwa media sangat menarik untuk dipergunakan dalam pembelajaran dan dapat memotivasi siswa serta meningkatkan antusiasme belajar. Hal ini sesuai dengan pendapat Sahni dan Sharma(2012) bahwa "to improve the level of understanding, develop the interests of trainees and purposeful enhancement of motivation, an alternative process of teaching was to be adopted. Multimedia was one of the solutions to overcome this".

Berdasarkan hasil evaluasi software multimedia interaktif pembelajaran IPA yang dikembangkan oleh ahli media(Tabel 9) menunjukkan rerata skor untuk aspek desain tampilan dan aspek program termasuk kategori sangat baik. Setelah menganalisis hasil evaluasi ahli media mengenai software(kategori sangat baik) dan tidak ada saran perbaikan dari ahli media, maka softwaremultimedia interaktif tidak dilakukan revisi dan dapat dipergunakan dalam uji coba lapangan. Komentar dari ahli media yang menyatakan bahwa desain yang disajikan sudah bagus karena tampilan sangat atraktif dengan tombol navigasi yang dinamis dan variatif sehingga pengguna dapat berinteraksi. Hal ini sesuai dengan pendapatEngland \& Finney(2011) bahwa "Interactive media is the integration of digital media including combinations of electronic text, graphics, moving images, and sound, into a structured digital computerised environment that allows people to interact with the data for appropriate purposes". Total rerata skor untuk semua aspek materi, teknik, desain tampilan, dan program dalam evaluasi softwareadalah 3,8 (sangat baik).

Berdasarkan evaluasi oleh para ahliyang mencakup aspek materi, teknik, desain tampilan, dan program dengan hasil sangat baik, maka dapat disimpulkan bahwa softwaremultimedia interaktif pembelajaran IPA sangat baik dan dapat dipergunakan dalam kegiatan pembelajaran. Hasil penelitian ini sejalan dengan hasil penelitian yang dilakukan oleh Widayat(2014) yang menyatakan bahwa multimedia interaktif efektif dalam meningkatkan hasil belajar dan sangat baik digunakan sebagai media pembelajaran IPA.

2. Hasil Belajar 
Berdasarkan analisis data hasil tes tertulis, pembelajaran IPA menggunakan softwaremultimedia interaktif terjadi peningkatan hasil belajar. Hal ini dapat dilihat perbedaan rerata nilai postes (nilai ulangan II) dibandingkan dengan ulangan harian sebelumnya (nilai ulangan I) ditunjukkan pada tabel 8, gambar 11 dan 12. Hal tersebut menunjukkan bahwa hasil tes tertulis setelah pembelajaran menggunakan softwaremultimedia interaktif lebih baik.

Nilai hasil tes tertulis (postes) pada kelas uji coba produk (Tabel 8 dan Gambar 13) diperoleh persentase nilai ketuntasan belajar secara klasikal sebesar 93\%, dengan demikian terjadi peningkatan 33\% dari persentase nilai awal (60\%). Terdapat 28 siswa yang memperoleh nilai di atas KKM $(\geq 70)$ dari jumlah seluruh siswa (30 siswa). Persentase ketuntasan belajar secara klasikal ini sudah memenuhi kriteria yang ingin dicapai dalam penelitian. Sebagaimana pernyataan Mulyasa (2010) bahwa ketuntasan belajar klasikal dinyatakan berhasil jika persentase ketuntasan belajar siswa yang memperoleh nilai sesuai KKM sekurang-kurangnya $85 \%$ dari jumlah seluruh siswa di kelas.

Berdasarkan ketuntasan belajar klasikalyang telah dicapai, maka dapat disimpulkan bahwa softwaremultimedia interaktif pembelajaran IPA yang dikembangkan efektif dalam meningkatkan hasil belajar. Hasil penelitian ini sejalan dengan hasil penelitian Yueh et al.(2012) yang menunjukkan bahwa multimedia membantu meningkatkan pemahaman mereka tentang konten pembelajaran.

Merujuk dari hasil uji produk yang telah dilakukan, maka tujuan penelitian untuk menghasilkan softwaremultimedia interaktif pembelajaran IPA efektif meningkatkan hasil belajar telah tercapai.

\section{KESIMPULAN DAN DARAN}

A. Kesimpulan

Berdasarkan hasil penelitian dapat disimpulkan bahwa:

1. Software multimedia interaktif pembelajaran IPA berdasarkan penilaian ahli materi dan ahli media dalam aspek materi, teknik, desain tampilan, dan program sangat baik (rerata skor 3,8) dan dapat dipergunakan dalam kegiatan belajar belajar.

2. Softwaremultimedia interaktif pembelajaran IPA efektif dalam meningkatkan hasil belajar berdasarkanketercapaian ketuntasan belajar klasikal sebesar $93 \%$ melalui uji coba lapangan.

B. Saran 
Jurnal IImiah Teknologi - Informasi dan Sains (TeknoIS)

Volume 7 Nomor 1 Bulan M ei 2017

p-ISSN : 2087-3891 dan e-ISSN : 2597-8918

1. Guru yang memberikan pelajaran dengan menggunakan media komputer sebaiknya hadir lebih awal sebelum pembelajaran dimulai untuk menyiapkan peralatan yang akan digunakan.

2. Bagi peneliti lain yang akan melakukan penelitian pengembangan sejenis dengan tema berbeda, harus dapat menentukan tema yang tepat sehingga menghasilkan materi yang mudah dipahami oleh siswa.

3. Jika waktu penelitian lebih panjang, maka penelitian selanjutnya diharapkan dapat meneliti dengan lingkup lebih luas yang melibatkan beberapa sekolah dalam satu kecamatan.

\section{DAFTAR RUJUKAN}

Arsyad, Azhar. 2013. Media Pembelajaran. Jakarta: Raja Grafindo Persada.

Candiasa,1 Made. (2012). Pembelajaran Berbasis Komputer. [Online] Tersedia: http://www.pasca undiskha.ae.id/e-learning/staff/images/img_info/6/25-493.pdf [24 April 2016].

England, E. and Finney, A. (2011). Interactive Media-What's that? Who's involved? ManagingInteractive Media. UK: ATSF.

Fraenkel, J. R., Wallen, N. E., and Hyun, H. H. (2015). How to Design and Evaluate Research in Education. New York: McGraw-Hill Education.

Kamat, V. and Shinde, J. (2009). Enrichment of Learning Experienceof Rural Children Through Interactive. [Online] Tersedia: https://www.wikieducator.org/image/5/5a/PID_598.pdf [25April 2016].

Keller, J. (2015). Models And Theories: Keller's ARCS Model of Motivation. [Online]

Tersedia: http://www.elearningindustry.comkres-model-of-motivation [29 April 2016].

Mulyasa, E. (2010). Kurikulum Berbasis Kompetensi: Konsep, Karakteristik dan Implementasi. Bandung: Remaja Rosdakarya.

Sahni, M. and Sharma, A. (2012). Multimedia compared to Text for Online. Asian Journal of Distance Education. 10 (1), 35-44.

Sugiyono. (2014). Metode Penelitian Kuantitaf, Kualitatif dan R\&D; Cetakan ke-2. Yogyakarta: Andi.

Vaishnav, R. and Parage. P. (2013. Innovative Instructional Strategies Interactive Multimedia Instruction And Computer Aided lnstruction For Teaching Biology. Voice of Research [Online], Vol 2 (2), 1-4. Tersedia: http://www.voiceofresearch.org/doc/Sep-2013_1.pdf [28 April 2016]. 
Jurnal IImiah Teknologi - Informasi dan Sains (TeknoIS)

Volume 7 Nomor 1 Bulan M ei 2017

p-ISSN : 2087-3891 dan e-ISSN : 2597-8918

Widayat, W., Kasmui dan Sukaesih, S. (2014). Pengembangan Multimedia Interaktif sebagai

Media Pembelajaran IPA Terpadu pada Tema Sistem Gerak pada Manusia. Unnes

Science Education Journal. 3 (2), 535-541.

Yueh, H. P., Lin, W., Huang, J. Y. and Sheen, H. J. (2012). Effect of Student Engagement on Multimedia-Assisted Instruction. [Online] Tersedia: http://www.kmeljournal.org/ojs/index.php/onlinepublication/article/viewFile/160/144 $\left[\begin{array}{ll}29 & \text { April }\end{array}\right.$ 2016]. 